\title{
Correction: Vacuum-assisted right atrial infected clot extraction due to persistent bacteraemia: a percutaneous approach for the management of right-sided endocarditis
}

Ahmed M, Montford JH, Lau E. Vacuum-assisted right atrial infected clot extraction due to persistent bacteraemia: a percutaneous approach for the management of rightsided endocarditis. BMJ. doi:10.1136/bcr-2018-226493.

The previous version of this manuscript contains an error in author's surname namely Jaime Hernandez Montford. It should read as:

Jaime Hernandez Montfort

instead of

Jaime Hernandez Montford

Also, the location of Baystate Medical Center should read as:

Baystate Medical Center, Springfield, MA, USA

Instead of

Baystate Medical Center, Springfield, Illinois, USA

(C) BMJ Publishing Group Limited 2018. No commercial re-use. See rights and permissions. Published by BMJ.

BMJ Case Rep 2018. doi:10.1136/bcr-2018-226493corr1

D) Check for updates

Copyright 2018 BMJ Publishing Group. All rights reserved. For permission to reuse any of this content visit http://group.bmj.com/group/rights-licensing/permissions.

BMJ Case Report Fellows may re-use this article for personal use and teaching without any further permission.

Become a Fellow of BMJ Case Reports today and you can:

- Submit as many cases as you like

- Enjoy fast sympathetic peer review and rapid publication of accepted articles

- Access all the published articles

Re-use any of the published material for personal use and teaching without further permission

For information on Institutional Fellowships contact consortiasales@bmjgroup.com

Visit casereports.bmj.com for more articles like this and to become a Fellow 